\title{
Vertical distribution of earthworms in grassland soils of the Colombian
}

"Llanos"*

\section{J. J. Jiménez ${ }^{\dagger 1}$ and T. Decaëns ${ }^{2}$}

† Departamento de Biología Animal I (Zoología). Facultad de Biología. Universidad Complutense. 28040. Madrid, Spain / Soil and Plant Nutrition Unit, CIAT. AA 6713, Cali. Colombia.

${ }^{2}$ Laboratoire d'Ecologie. UFR Sciences Université de Rouen. 76821 Mont Saint Aignan Cedex, France.

${ }^{1}$ Corresponding author

Present address:

Soil and Plant Nutrition Unit. Centro Internacional de Agricultura Tropical (CIAT). AA 6713, Cali, Colombia

Phone number: 5724450000

Fax number: $\quad 5724450073$

e-mail: j.jimenez@cgiar.org

* This paper is dedicated to the memory of my uncle Juan and my aunt Ramona 


\begin{abstract}
The vertical distribution of native earthworm species from natural and disturbed savannas in the oxisols of the Colombian Llanos was assessed in a native savanna and in a 17yr old grazed grass-legume pasture during 17 months. Different patterns of vertical stratification were observed for all species with a strong migration of populations to deeper layers in the dry season. The correlation between the size of the earthworms and the average depth at which they were found was not significant $(\mathrm{p}>0.05)$ despite that bigger species locate deeper in the soil. The living habits and adaptive strategies of the smallest species, Ocnerodrilidae n. sp. found in both ecosystems studied are responsible for this pattern. This endogeic species is associated with organic pools of an anecic species and further studies should assess the role of this species in ecosystem functioning. Mature worms of one anecic species were located deeper than immature ones in the soil $(\mathrm{p}<0.01 * *)$. Soil moisture had an important effect on the vertical distribution of earthworms, although differences between immature and mature worms of the anecic Martiodrilus carimaguensis are likely to be of biotic origin. New data on the biology and ecology of these Neotropical species are shown.
\end{abstract}

Key words: Earthworms, Savannas, Vertical distribution, Adaptive strategies, Disturbance 


\section{Introduction}

Vertical distribution of soil fauna is one of the factors reponsible for niche partitioning in macrofaunal communities of soils, reducing both inter- and intraspecific competition among taxa. Amongst the soil fauna little work has been done on niche differentation. Kaczmareck (1975) and Curry (1978) studied niche width amongst soil Arthropods, Vegter (1983) for some Collembola species distributed along a moisture gradient, and Davidson (1985) and Lynch et al. (1980) for granivorous ants. In earthworms, Krishnamoorthy (1985) found a certain degree of niche differentation related to vertical zonation, explained by soil organic matter content and moisture at different depths.

The distribution of earthworms within the soil profile is determined by both abiotic (i.e. moisture and temperature) and biotic (behavioural) factors (Martin and Lavelle 1992). Soil moisture is an essential factor that determines the degree of activity and location in the soil profile of earthworms since they are animals with cutaneous respiration (Lavelle 1983; Lee 1985), extracting water from the soil they ingest (Barois and Lavelle 1986).

Vertical pattern has been less studied in tropical than in temperate ecosystems. Reddy and Pasha (1993) studied the vertical distribution of earthworms in semiarid Indian grassland soils; Senapati (1980) in grazed and ungrazed plots of India; Németh and Herrera (1982) in a Venezuelan tropical rain forest in acid soils; Lavelle (1978) in different savanna facies at Lamto (Ivory Coast) and Fragoso (1993) in Southeastern Mexican natural and disturbed systems. In tropical systems, where environmental conditions are characterized by a strong seasonality, earthworms migrate deeply in to the soil to aestivate in different ways, i.e. quiescence or diapause (Lavelle 1978; Fragoso 1985, 1993; Jiménez et al. 1998a).

Some authors have also reported data on differences in the vertical distribution between immature and mature worms. Satchell (1955) found that adults and nearly mature worms of some European lumbricid species were found deeper in the soil than immature individuals. This has also been observed by Gerard (1967) in British pastures where mature worms retreated deeper in the soil before entering a resting stage. Piearce (1983) also confirmed this and found juveniles living closer to the surface than adults, while in northern Spain, Mato et al. (1988) found this pattern for two lumbricid species. In Tasmania, Garnsey (1994) reported that juveniles were 
located at a shallower depth on entering aestivation than adults. The reasons usually given to explain this pattern are the depth at which cocoons are laid and, as a result, juveniles hatch, and the weak burrowing ability of small juveniles in comparison with adults.

Vertical distribution of earthworm species in the soil is normally used as a criterion for their classification into ecological categories (Lee 1959, 1985; Bouché 1972; Lavelle 1981, 1988). The size of earthworms is another feature that some authors have related to vertical pattern, i.e. the larger the earthworm the deeper it burrows (Piearce 1983). Lavelle (1978) and Fragoso (1993) found a positive relation between the vertical distribution of earthworm species and their size in the savannas of Lamto (Ivory Coast) and alluvial acid soils of Chiapas (Mexico), respectively.

There is increasing interest in descriptions of soil biodiversity and the understanding of the processes that explain the functioning of communties, either in natural or disturbed ecosystems (Giller 1996). In the savannas of Carimagua, in the eastern plains of Colombia, several studies were and are being conducted to investigate these processes in an area where no previous attempt to gain knowledge of the soil fauna has been carried out (Decaëns et al. 1994, Decaëns et al. 1999a; Decaëns et al. 1999b; Jiménez et al. 1998a, 1998b, 1999).

Description and explanation of the vertical distribution of earthworm communities is a necessary part of the study of population patterns in order to have as many tools as possible if future management of natural resources, i.e. earthworms, is to be pursued. In this study our objective was to establish the seasonal vertical pattern of the earthworm community in a native savanna and an intensive pasture from the well drained isohyperthermic savannas of Colombia. Its relation with both soil moisture and size of different earthworm species is assessed and discussed.

\section{Materials and methods}

Site description

The study was conducted at Carimagua research station (CIAT-CORPOICA agreement) on the well-drained isohyperthermic savannas in the Eastern Plains of Colombia ( $4^{\circ} 37^{\prime} \mathrm{N}, 71^{\circ} 19^{\prime} \mathrm{W}$ and 175 meters altitude). Yearly average rainfall and temperature are respectively $2280 \mathrm{~mm}$ and $26{ }^{\circ} \mathrm{C}$ (from 1972 to 1995 , CIAT data), with a severe dry period from December to March. Soils at the study site have been defined (USDA) as fine, kaolinitic, isohyperthermic typic haplustox (clay loam soil), of supposedly low fertility. They are characterized by their acidity 
$(\mathrm{pH}=4.5$, in water), a high $\mathrm{Al}$ saturation $(>90 \%)$ and low values of exchangeable $\mathrm{Ca}, \mathrm{Mg}$ and $\mathrm{K}$ (Lascano and Estrada 1989).

Two different plots were studied: (1) herbaceous ungrazed natural savanna where an accidental fire ocurred two years before the sampling period started; (2) a 17-yr old grazed pasture where an exotic African grass, Brachiaria decumbens cv. Basilisk is associated with a herbaceous legume, Pueraria phaseoloides CIAT 9900 ("kudzú"). Pasture was fertilized with $\left(\mathrm{kg} \mathrm{ha}^{-1}\right) 44 \mathrm{P}, 40 \mathrm{~K}, 14 \mathrm{Mg}$ and $22 \mathrm{~S}$ at establishment and with $10 \mathrm{P}, 9 \mathrm{~K}, 92.5 \mathrm{Ca}, 9 \mathrm{Mg}$ and 11.5 S each second year for the subsequent nine years (Lascano and Estrada 1989). Stocking rates for the improved pasture are 1 cattle ha $^{-1}$ in the dry season ("verano") and 2 cattle ha $^{-1}$ in the wet season ("invierno").

\section{Earthworm sampling}

From March 1994 to September 1995 soil samples were monthly taken in the savanna and pasture systems. No samples were collected in June 1994 since labour was not available. In each system a stratified random sampling programme was conducted in a $90 \times 90 \mathrm{~m}$ plot divided into regular quadrats of $10 \times 10 \mathrm{~m}$ that were grouped in five zones. Two types of physical method were used (after Lavelle, 1978): hand sorting of $1 \mathrm{~m}^{2} \mathrm{x} 0.5 \mathrm{~m}$ depth and washing-sieving of $20 \times 20 \mathrm{~cm} \times 20 \mathrm{~cm}$ depth samples. From each plot, five $1 \mathrm{~m}^{2}$ and 10 washing-sieving monthly samples were taken randomly (except for March 1994, $\mathrm{n}=3$ and 6, respectively). Samples for washing-sieving were collected at both sides of the $1 \mathrm{~m}^{2}$ block.

A trench was dug around the quadrat to avoid possible escape of some individuals laterally out of the block and to facilitate the separation of layers into $10 \mathrm{~cm}$ depth increments. The sampling depth for sorting varied seasonally to take into account the vertical migration of some species, e.g. Martiodrilus carimaguensis (Jiménez and Moreno, in press), which shows strong evidence of diapause and is normally found during the dry season around $80 \mathrm{~cm}$ depth (Jiménez et al. 1998a). All earthworms were carefully collected, washed in water and fixed in $4 \%$ formalin (10\% of the commercial solution). They were separated into species in the laboratory and adults (clitellum present), subadults (no clitellum but sexual marks), immatures (clitellum and sexual marks absent) and cocoons, were counted and weighed.

\section{Soil moisture}

Soil cores were taken in all sampled layers on each sampling ocassion. To calculate the water content in the soil (\% dry soil weight), six subamples were separated for each layer, weighed (nearly $100 \mathrm{~g}$ wet soil) and oven-dried at $60^{\circ} \mathrm{C}$ for at least four days.

Earthworm community in the savanna and pasture

The earthworm community in the savanna and pasture comprises 8 species new to science that will be described elsewhere. All species are native, even in the pasture, and of diverse sizes and ecological functions (Jiménez et al. 
1998b). Despite the maintenance of the species richness the H' index (Shannon and Weaner, 1949) decreases when the natural system is converted into introduced pasture, from 2.89 to 1.29 , due to the fact that one anecic species accounts for $88 \%$ of the total earthworm biomass (Jiménez et al. 1998b). Whereas density of earthworms is very similar in the pasture system in relation to the savanna (130.3 against 114.5 ind. $\mathrm{m}^{-2}$ ), biomass is more than ten times higher, i.e. 59.4 against $4.8 \mathrm{~g}$ f.w. $\mathrm{m}^{-2}$. The vertical patterns were assessed for only six species: Andiodrilus n. $\mathrm{sp}$. (endogeic mesohumic), Andiorrhinus n. sp. (endoanecic), Aymara n. sp. (epigeic), Glossodrilus n. sp. (endogeic polyhumic), M. carimaguensis (anecic) and Ocnerodrilidae n. sp. (endogeic polyhumic).

Statistical analysis

A simple linear regression analysis (Pearson $\mathrm{r}$ ) was used to study the correlation between some variables, i.e. length/diameter and weight/diameter ratios to vertical distribution, or both density and biomass against soil moisture content. T-test and analysis of variance (ANOVA) were employed to test for significant differences between means. Finally, a non-parametric Kruskal Wallis ANOVA was used to compare variables under the assumption of distinct sample size. The statistical SPSS package was used in all cases and SigmaPlot Jandel Scientific graphic software for presentation of figures.

\section{Results}

\section{Vertical distribution of species}

The assessment of the vertical pattern of earthworm populations allows us to determine those layers that will be exploited by the different species. The yearly average vertical pattern of earthworm species in the two plots studied from July 1994 to June 1995 is expressed in Table 1. Land management had no effect on the vertical distribution of earthworm species, except for $\underline{\mathrm{M}}$. carimaguensis (ANOVA, $\mathrm{P}<0.001$ ). Monthly average soil moisture contents were significantly different between the two land management systems $(P=0.028$, t-test $)$; however, differences between soil layers in moisture content were not significant (ANOVA, $\mathrm{P}>0.05$ ).

Three species lived at an average depth of 0-10 cm: Andiodrilus n. sp., Aymara n. sp. and Glossodrilus n. sp. Andiorrhinus n. sp. lived at an average depth of $12 \mathrm{~cm}$ in the pasture (no individuals were recorded in the savanna plot between July 1994 and June 1995). Two species

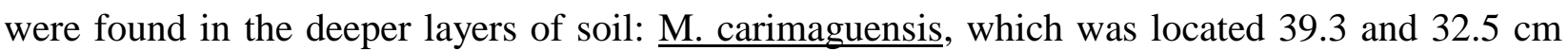
beneath the soil and the small Ocnerodrilidae n. sp. that was found living at an average depth of 
25.4 and $22.7 \mathrm{~cm}$ in the savanna and in the pasture, respectively.

The percentage of the population of Andiodrilus n. sp. found in the different layers of soil in both systems is illustrated in Figure1a. In the savanna most of the population was located in the first two layers, $68.6 \%$ in the $0-10 \mathrm{~cm}$ layer and $20,4 \%$ in the second, with a maximum reached depth of $40 \mathrm{~cm}$. In the pasture similar values were found, with $74 \%$ of the whole population in the first $10 \mathrm{~cm}$ and $19.7 \%$ in the second layer.

Andiorrhinus n. sp. was not found in the savanna, so the vertical distribution is based only on values obtained in the pasture (Fig. 1b). The few specimens collected show that nearly $80 \%$ of the total population was found in the first layer, with a maximum depth of $60 \mathrm{~cm}$.

In the savanna individuals of Aymara n. sp. were almost equally distributed in the first two layers and only $5.4 \%$ were found in the $20-30 \mathrm{~cm}$ layer (Fig. 1c). In the pasture, nearly all the population was located in the first $10 \mathrm{~cm}$ of the soil profile.

Glossodrilus n. sp. was mainly found in the topsoil. During the dry season the maximum depth at which individuals were collected was $80 \mathrm{~cm}$ (Fig. 1d). In the savanna $76 \%$ of the population were located in the $0-10 \mathrm{~cm}$ layer, numbers declining with soil depth. In the pasture, $90.2 \%$ of the individuals were found in the first $10 \mathrm{~cm}$ of soil; some specimens appeared in the 70-80 $\mathrm{cm}$ layer.

The yearly average vertical pattern for $\underline{M}$. carimaguensis is shown in Figure 1e. Only 9 specimens were found in the natural savanna in one year, so comparisons with vertical distribution in the pasture are tentative. In the latter system, the 0-10 $\mathrm{cm}$ and 40-50 cm layers had the highest values, i.e. 21.3 and $19.2 \%$, respectively. This reflects the seasonal variations in vertical depth of this species. Nearly the same percentage of the population was located in each of the remaining layers down to $60 \mathrm{~cm}$ (values ranged from 11.2 to $13.4 \%$ ); 8.2 and $1.7 \%$ of the total density was found in the 60-70 and 70-80 cm layers, respectively.

For Ocnerodrilidae n. sp., about $95 \%$ of the individuals in the savanna were rather homogeneously distributed down to $50 \mathrm{~cm}$ (Fig. 1f). Less than $5 \%$ of the total was found beneath this depth, to a maximum of $80 \mathrm{~cm}$. In the pasture $22.6 \%$ of the individuals were situated in the 0 $10 \mathrm{~cm}$ layer and similar values were obtained in the following two layers. Respectively 10.5 and $9.9 \%$ of the whole population were located at $30-40$ and $40-50 \mathrm{~cm}$, and only $5 \%$ of the total population was found from 50 to $80 \mathrm{~cm}$. 
Earthworm size related to vertical pattern

Some authors have attempted to determine relationships between some biometric variables of earthworm species and their vertical distribution (Lavelle 1978; Fragoso 1993). A positive correlation between the length of the lumbricid body and the depth of burrowing into the soil was suggested by Piearce (1983).

The length/diameter (L/D) and weight/diameter (W/D) ratios have been related to yearly average vertical distribution (Fig. 2: a, b). However, no statistically significant relationship appeared to exist $(\mathrm{P}>0.05)$ and this was due to the presence of Ocnerodrilidae $\mathrm{n}$. sp. If this species had not been present in the earthworm community correlations would have been statistically significant, as it is associated with organic matter pools such as litter and root decomposition compartments (Decaëns, unpubl.), nests of Coleopteran species and burrows of $\underline{\mathrm{M}}$.

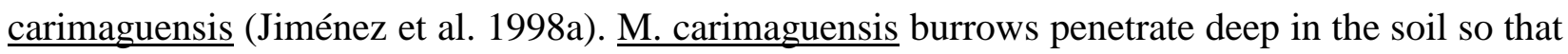
Ocnerodrilidae n. sp., in spite of its size, can be found at a great depth. Larger species are not necessarily located in the deeper layers of the soil profile.

In accordance with the ecological classification of earthworms by Lee (1959, op. cit. in 1985) we found litter, topsoil and subsoil species. Aymara n. sp. may be considered as a litter species with a L/D value ranging from 33 in the savanna to 29.0 in the pasture, Andiodrilus n. sp. and Glossodrilus sp. as topsoil species with L/D ratios from respectively 20 to nearly 53, Andiorrhinus sp. and Ocnerodrilidae n. sp. as intermediate topsoil/subsoil species with L/D ratios from 22.9 to 32.4 , although the inclusion of the latter species in such an ecological category is

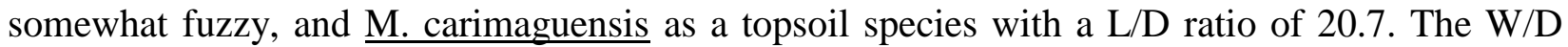

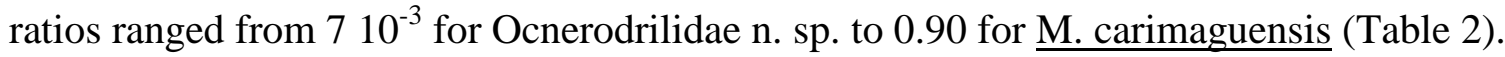

Vertical distribution of aestivation in $\underline{\text { M. carimaguensis }}$

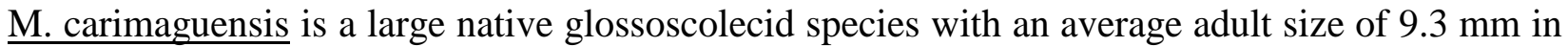
diameter and $194.3 \mathrm{~mm}$ in length and fresh weight of $11.2 \mathrm{~g}$ (in $4 \%$ formalin) $(\mathrm{n}=29)$. Its body colour is dark grey on the dorsal side and light grey on its ventral side (Jiménez et al. 1998a). This species, a typical anecic (sensu Bouché 1972), shows strong evidence of vertical migration, and 
there are important differences in the beginning of diapause between immature and mature worms. Whilst adults enter diapause at the end of the rainy season, in November and December, inmature worms will initiate it four months before, in July and August (Jiménez et al., 1998a).

Normally, more aestivating immature worms were found in the $40-50 \mathrm{~cm}$ layer than in other layers, whilst both adults and subadults were located in the 50-60 cm layer (Fig. 3). Without taking into account the demographical stage of the whole population, a significant non-linear correlation was found between the weight of worms in diapause and their location in the soil profile (Kruskal-Wallis ANOVA, $\mathrm{P}=0.011$ ). The larger the individual the deeper it aestivates (Fig. 4) and their average weight ranged from 1 to $2.5 \mathrm{~g}$ ( $4 \mathrm{~g}$ maximum), which is very low when compared to the fresh adult weight. This is the result of emptying their guts to coil themselves up in their aestivating chambers.

\section{Vertical distribution of cocoons}

The vertical pattern of cocoons could be assessed only for three species: Andiodrilus n. sp.,

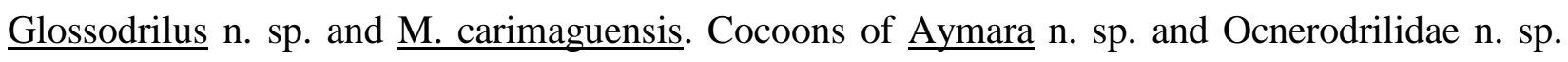
were not obtained as they were probably destroyed by the washing-sieving method. The mean depth at which cocoons were laid has been calculated from the total number collected in each layer (Fig. 5 a-c)

The mean cocoon deposition depth for Andiodrilus n. sp. was 6.5 and $5.6 \mathrm{~cm}$ in savanna and pasture systems respectively. Most of the cocoons were found in the topsoil (Fig. 5a).

The first layer was also the most used by Glossodrilus n. sp. to lay its cocoons and the mean depth was $8.7 \mathrm{~cm}$ in the savanna and $12.4 \mathrm{~cm}$ in the pasture (Fig. $5 \mathrm{~b}$ ). These data refer to the number of cocoons obtained by the washing-sieving method; since some cocoons were obtained below $20 \mathrm{~cm}$ depth in the $1 \mathrm{~m}^{2}$ soil monoliths, a correction in the percentage of cocoons found is needed. For this reason, we considered that $95 \%$ of the total number of cocoons were located in the first $20 \mathrm{~cm}$ and $5 \%$ in the $20-30 \mathrm{~cm}$ layer in the savanna. On the other hand, $85 \%$ of the cocoons were found in the $0-20 \mathrm{~cm}$ layer and $15 \%$ in the $20-40 \mathrm{~cm}$ layer in the pasture. Probably, a small fraction of cocoons was placed deeper than $20 \mathrm{~cm}$ in the soil and were not collected by the washing-sieving technique. Hence data from hand-sorted $1 \mathrm{~m}^{2}$ samples were considered as a valid 
assessment.

The vertical distribution of cocoons for $\underline{M}$. carimaguensis could only be determined in the pasture. No Figure is shown for the cocoons of this species in the savanna as only one cocoon was collected in the fourth sample of July 1994 (in the 20-30 cm layer). Cocoons were found at a mean depth of $26 \mathrm{~cm}$, reaching a maximum of $50 \mathrm{~cm}$. More than $50 \%$ of the cocoons were placed in the 20-30 cm layer (Fig. 5c).

Seasonal variations

All the species considered followed a uniform vertical pattern during the rainy season, with a large proportion of individuals within the first $20 \mathrm{~cm}$. In the dry season earthworm populations were located deeper in the soil, associated with changes in soil moisture. In both systems a oneway ANOVA procedure showed significant differences in soil moisture content between both the rainy and dry seasons in the $0-10 \mathrm{~cm}$ layer (Fig. 6). When the land-use system was introduced into the analysis as a covariate, significant differences $(\mathrm{P}<0.05)$ only appeared in the first three layers (to 20-30 cm). This is explained by the high variations in moisture content in the upper layers of soil profile. The moisture content of all layers to $50 \mathrm{~cm}$ in both dry and wet seasons for the two systems evaluated is shown in Fig. 7.

Differences appeared, however, between the vertical distribution of adults and juveniles in the

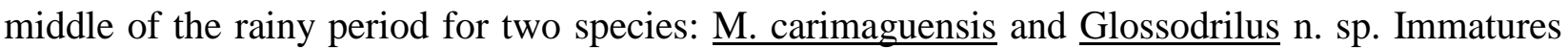

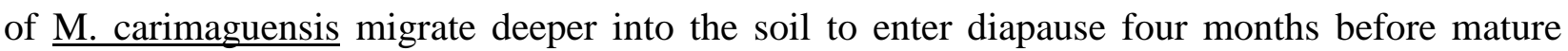
individuals (Jiménez et al. 1998a). The seasonal pattern of vertical distribution for both species is shown in Fig. 8. At the onset of the rainy period in the first year most of the population of these two species was located in the first $20 \mathrm{~cm}$ of the soil profile. By the middle of this season, besides changes that occurred in the demographic stage of the population, the deeper layers of the soil contained an important proportion of inactive individuals, especially immatures belonging to $\underline{\mathrm{M}}$. carimaguensis, in contrast to adults, which were still active in the first $20 \mathrm{~cm}$. In the savanna plot, immature worms of Glossodrilus n. sp. began to move down in August 1994, increasing in abundance in the deeper layers of soil with time. In October 1994, the population of Glossodrilus n. sp. consisted completely of adults, still located preferentially in the $0-10 \mathrm{~cm}$ layer. On the 
contrary, M. carimaguesis seemed to be divided into two groups; adults were still collected in the first $20 \mathrm{~cm}$ and from this layer downward immatures, subadults and cocoons were found, with some adults. In January 1995, when no stimulus for activity had affected the earthworm community (Jiménez et al. in prep.), only cocoons and immatures, that were aestivating inside a transparent mucus sphere, resembling a cocoon (Jiménez, unpubl.) at 20-40 cm depth, comprised the whole population of Glossodrilus $n$. sp. Some adults and many immatures of $\underline{M}$. carimaguensis were found in the layers from 20 to $80 \mathrm{~cm}$.

There seemed to be a delay in ceasing activity in the pasture compared with the savanna for Glossodrilus n. sp. With the onset of the rainy season earthworms were all located in the $0-10 \mathrm{~cm}$ layer again. However, in the pasture immature worms were several months longer than in the savanna in the first layer, and by the end of the rainy season the whole population was almost totally made up of adults.

\section{Discussion}

Generally, the replacement of original ecosystems by different land use systems of human causes a deep impact on the functioning of the ecosystem. For example, native earthworm communities are either completely depleted or drastically reduced when tropical ecosystems are replaced by both high input monocultures and intensive pastures (Fragoso and Lavelle 1992; Fragoso 1993; Barros et al. 1996). In contrast, the conversion of the savanna into introduced pasture had no effect on the vertical distribution of the earthworm community studied in Carimagua.

The lack of a clear relationship between the biometric variables employed, i.e. L/D and W/D ratios, and the vertical distribution of earthworm species does not differ from other studies (Lavelle 1978, Fragoso 1993, Németh and Herrera 1982) where larger species were found deeply distributed in the soil profile. Our results can be explained from the living habits of the species Ocnerodrilidae n. sp., a very small polyhumic ( $\underline{\text { sensu }}$ Lavelle 1981) earthworm (5 10 ${ }^{-3}$ g.f.w. and $19.2 \mathrm{~mm}$ length) living at an average depth of 25.4 and $22.7 \mathrm{~cm}$ in the savanna and the pasture, respectively. This species is, at least, partially associated with the deep vertical burrows of $\underline{M}$. carimaguensis. The vertical distribution of this species therefore depends on the galleries filled with faeces of the large anecic species. Ocnerodrilidae n. sp. may be considered as one of a group 
of earthworms adapted to very special and specific environments. Bouché (1972) proposed the french term "pholéophiles" worms for those epigeic species inhabiting the burrows of other earthworm species. Saussey (1956), Bouché (1970) and Piearce (1983) found that the surfacedweller, Dendrobaena mammalis (Lumbricidae) inhabits the burrows of the endogeic deepburrowing Allolobophora longa (Lumbricidae). Ocnerodrilidae n. sp. would be a particular case of an endogeic worm associated with the burrows constructed by an anecic species.

The significant differences $(\mathrm{p}<0.05)$ obtained in the soil moisture content in the first three strata when the land-use system was introduced as a covariate might be due to differences in various factors. For example, type of vegetation, amount of litter deposited on the soil surface, root distribution and physical structure of soil, among others, may affect the hydraulic properties and, for instance, water content in the soil in both systems.

Though soil moisture content has an important effect on the vertical distribution of earthworms, the differences between immature and mature worms of $\underline{\mathrm{M}}$. carimaguensis are likely to be of biotic origin. The earlier entrance of immature worms into diapause is physiologically induced as no response occurred when immature individuals were introduced into soil with $\mathrm{pF} 2.5$ (Jiménez et al. 1998a). The reason for these differences might be an adaptive strategy of large topsoil species to avoid higher densities of individuals in the upper layers of soil during the reproductive period. This supports results of Fragoso (1993) who showed that interspecific competition for nutrients in the topsoil may be a determinant factor in both the size and vertical distribution of endogeic earthworms.

On the basis of this study and from others it seems obvious that environmental factors influence the yearly vertical pattern of earthworm species, but in some cases physiologically induced factors may be responsible. Immature worms of $\underline{M}$. carimaguensis descend some decimetres in the middle of the rainy season to enter diapause. Further studies would be necessary to seek the reasons that determine this behavioural pattern.

Lee (1959) classified the earthworm fauna of New Zealand and concluded that litter species had L/D ratios from 8 to 17, topsoil species values ranging from 15 to 40 and subsoil species from 20 to 130. Lavelle (1978) obtained similar values for the African megascolecid fauna. At Carimagua Glossodrilus n. sp. is a topsoil species but an exception as its L/D ratio is 53 (long and narrow). 


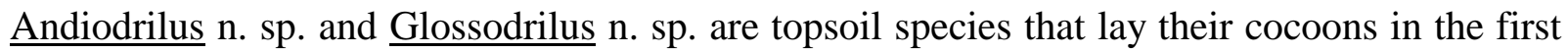
$20 \mathrm{~cm}$, principally at $0-10 \mathrm{~cm}$ depth. Immatures of both species, after hatching, were located

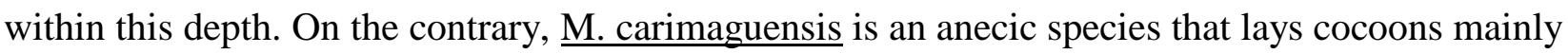
at 20-30 cm depth and the yearly average vertical depth for immatures was $35 \mathrm{~cm}$. When newly hatched immature worms emerge, at the end of the rainy season, they retreat deeper to aestivate (Jiménez et al. 1998a).

Large body size may be an adaptation to resist dryness and may provide resistance to starvation (Piearce 1983). M. carimaguensis is the largest species found in the savannas and pastures of Carimagua and its strategy to resist the dry season is considered one of the most outstanding features encountered in the study of earthworm communities (Jiménez et al. 1998a). A high L/D ratio may be important for efficient respiration in an anaerobic environment (Piearce 1983), e.g. for Allolobophora (sensu lato) oculata oculata (Lumbricidae) or Haplotaxis gordioides (Haplotaxidae). At Carimagua, Glossodrilus n. sp. presents the highest L/D ratio and this could be an advantage over other species, especially after heavy rains that flood the land for some time.

At Carimagua, coexisting species, in both natural and disturbed systems studied, appear to be highly specialized, reducing competitive exclusion by differential use of resources. In the rainy season, although two topsoil species, i.e. Andiodrilus n. sp. and Glossodrilus n. sp., exhibit a high degree of niche overlap in relation to vertical dimension it seems clear that competition should be reduced along other dimensional axes, for example, by differences in the size of the species, seasonal patterns of abundance, adaptive strategies and life history (Jiménez, unpubl.) For instance, the way that species exploit different soil layers and feed upon soil aggregates and organic detritus of different size ranges and variable decomposition rates.

The adaptive strategies of $\underline{\mathrm{M}}$. carimaguensis result in a reduction of the temporal niche width. Immatures descend deeper into the soil to enter diapause four months before adults, which afterwards initiate their reproductive period. Since adults of this species invest nearly $16 \%$ of their weight into the formation of cocoons, the highest recorded to date (Jiménez et al. 1999), it seems obvious that this amount of energy is supplied by high-energy inputs, such as litter. A large number of individuals, immature and mature worms all together, would reduce these feeding resources and increase intraspecific competition.

Both abiotic and biotic factors, not quantitatively measured in this study, have an influence on 
the degree of competition among species and allow a reduction in it through partitioning of resources. A species that does not reduce its competition in the vertical dimension will do so in one of the other two major dimensions, temporal and trophic (Giller, 1984).

Biotic interactions, on the other hand, produce patterns in resource partitioning (Giller 1984). M. carimaguensis is capable of producing a diverse range of biogenic structures, i.e. burrows, aestivating chambers and large casting material on the soil surface that influence the surrounding environment (Decaëns et al. 1999b), other soil biota (Decaëns et al. 1999a) and soil seed banks (Decaëns et al, unpubl.) Hence, the functional approach must be mentioned as this species may be considered, without doubt, an ecosystem engineer (sensu Jones et al. 1994) since it directly or indirectly modulates the availability of resources to other species by causing physical state changes in biotic or abiotic materials (Decaëns in press; Decaëns et al. in press.) $\underline{M}$. carimaguensis creates structures, through its feeding, digging and casting activities, that can be considered new habitats for other organisms. Not only the small Ocnerodrilidae n. sp. is favoured by these processes but roots, which find a greater amount of trophic resources in those structures. Thus, we assume that engineering diversity promotes diversity at other trophic levels, resulting in a community of nested biodiversities (Lavelle 1996).

Acknowledgements This work was carried out within a research grant of the Macrofauna project (EC - STD2). We want to thank Professor Patrick Lavelle (IRD, France), and Drs. Richard J Thomas and Myles J Fisher (International Center for Tropical Agriculture, CIAT, Colombia) for their encouragement and enthusiasm to study the role of earthworms in the savannas and man-made pastures of Carimagua, in the Colombian "Llanos". The first author would like to thank Jean Pierre Rossi (IRD, France) and two anonymous referees for helpful comments and their criticism on a first version draft of this paper.

\section{References}

Barois I, Lavelle P (1986) Changes in respiration rate and some physicochemical properties of a tropical soil during transit through Pontoscolex corethrurus (Glossoscolecidae, Oligochaeta). Soil Biol Biochem 18: 539-541

Barros ME, Blanchart E, Neves A, Desjardins T, Chauvel A, Lavelle P (1996) Relaçao entre a macrofauna e agregaçao do solo em tres sistemas na Amazonia central. In: Solo/Suelo XII Congresso Latino America de Ciencia do Solo, Aguas de Lindoia, Brazil (in CD-Rom)

Bouché MB (1970) Relations entre les structures spatialles et fonctionelles des écosystèmes ilustrées par le rôle pédobiologique des vers de terre. In: Pesson P (ed). La Vie dans le Sol. Gauthiers-Villars, Paris. pp. 187-209 
Bouché MB (1972) Lombriciens de France. Ecologie et Systematique. I.N.R.A. Paris. 671 p

Curry JP (1978) Relationships between microarthropod communities and soil and vegetational types. Sci Proc Roy Dub Soc 6: 131-141

Davidson DW (1985) An experimental study of diffuse competition in harvester ants. Amer Nat 125: 500-506

Decaëns T, Lavelle P, Jiménez JJ, Escobar G, Rippstein G (1994) Impact of land management on soil macrofauna in the Oriental Llanos of Colombia. Eur J Soil Biol 30 (4): 157-168

Decaëns T, Mariani L, Lavelle P (1999a) Soil surface macrofaunal communties associated with earthworm casts in grasslands of the eastern plains of Colombia. Appl Soil Ecol 13: 87-100

Decaëns T, Jiménez JJ, Lavelle P (1999b) Effect of exclusion of the anecic earthworm Martiodrilus carimaguensis Jiménez and Moreno on soil properties and plant growth in grasslands of the eastern plains of Colombia. Pedobiologia 43: 835-841

Decaëns $T$ (in press) Degradation dynamics of surface earthworm casts in grasslands of the eastern plains of Colombia. Biol Fertil Soils (in press)

Decaëns T, Galvis J, Amézquita, E (in press) Properties of those structures created by soil ecological engineers from the Colombian savannas. C R Acad Sci (in press)

Decaëns T, Mariani L, Betancourt N, Jiménez JJ Earthworm effects of permanent soil seed banks in Colombian grasslands. Oikos (submitted)

Fragoso C (1985) Ecología general de las lombrices terrestres (Oligochaeta: Annelida) de la región Boca del Chajul, Selva Lacandona (Chiapas, Mexico). Tesis de grado, UNAM, Mexico

Fragoso C (1993) Les Peuplements de Vers de Terre dans L'Est et Sud-Est du Mexique. These de Doctorat, Université Paris 6. $228 \mathrm{p}+$ annexes

Fragoso C, Lavelle P (1992) Earthworm communities of tropical rain forests. Soil Biol Biochem 24 (12): 1397-1408

Garnsey RB (1994) Seasonal activity and aestivation of Lumbricid earthworms in the Midlands of Tasmania. Aust J Soil Res 32: 1355-1367

Gerard BM (1967) Factors affecting earthworms in pastures. J Anim Ecol 36: 235-252

Giller PS (1984) The community structure and the niche. Chapman and Hall, London, UK

Giller PS (1996) The diversity of soil communities, the "poor man's tropical rainforest". Biodiv Cons 5: 135-168

Jiménez JJ, Moreno AG (in press). Martiodrilus carimaguensis (Oligochaeta, Glossoscolecidae), una nueva especie de lombriz de tierra para Colombia. Megadrilogica

Jiménez JJ, Moreno AG, Lavelle P, Decaëns T. (1998a) Population dynamics and adaptive strategies of Martiodrilus carimaguensis (Oligochaeta, Glossoscolecidae), a native species from the well- drained savannas of Colombia. Appl Soil Ecol 9: 153-160

Jiménez JJ, Moreno AG, Decaëns T, Lavelle P, Fisher MJ, Thomas RJ (1998b) Earthworm communities in natural savannas and man-made pastures of the Eastern plains of Colombia. Biol Fertil Soils 28: 101-110

Jiménez JJ, Moreno AG, Lavelle P (1999). Reproductive strategies of three native earthworm species from the savannas of Carimagua (Colombia). Pedobiologia 43: 851-858.

Jones CG, Lawton JH, Shachak M (1994) Organisms as ecosystem engineers. Oikos 69: 373-386 
Kaczmarek M (1975) An analysis of Collembola communities in different pine forest environments. Ekol Polska 23: 265-293

Krishnamoorthy RV (1985) A comparative study of wormcast production by earthworm populations from grassland and woodland sites near Bangalore, India. Rev Ecol Biol Sol 22(2): 209-219

Lascano CL, Estrada J (1989) Long-term productivity of legume-based and pure grass pastures in the Eastern Plains of Colombia. In: Proceedings of the XVI International Grassland Congress, Nice, pp 1179-1180

Lavelle P (1978) Les vers de terre de la savane de Lamto (Côte d'Ivoire): peuplements, populations et fonctions dans l'ècosystème. Thèse de Doctorat, Paris VI. Publ. Lab. Zool. E.N.S., 12, 301 p

Lavelle P (1981) Strategies de reproduction chez les vers de terre. Acta Oecol 2 (2): 117-133

Lavelle P (1983) The soil fauna of tropical savannas. II. The earthworms. In: Bourlière F. (ed.). Tropical Savannas. Elsevier, Amsterdam. pp: 485-504

Lavelle P (1988) Earthworm activities and the soil system. Biol Fertil Soils 6: 237-251

Lavelle P (1996) Diversity of soil fauna and ecosystem function. Biol Int 33: 3-16

Lee K (1959) The earthworm fauna of New Zealand. New Zealand Department of Scientific and Industrial Research Bulletin 130

Lee K (1985) Earthworms: Their ecology and relationships with soils and land use. Academic Press, New York. 411 $\mathrm{p}$

Lynch J, Balinsky E, Vail S (1980) Foraging patterns in three sympatric forest ant species, Prenolepis imparis,

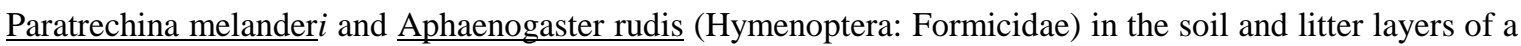
Maryland forest. Amer Midl Nat 119: 31-44

Martin S, Lavelle P (1992) A simulation model of the vertical movements of an earthwom population (Millsonia anomala, Omodeo, Megascolecidae) in an African savanna (Lamto, Ivory Coast). Soil Biol Biochem 24 (12): $1419-1424$

Mato S, Mascato R, TrigoD, Díaz-Cosín DJ (1988) Vertical distribution in soil of earthworms in Sierra del Caurel 1. Species and vegetation types. Pedobiologia 32: 193-200

Nemeth A, Herrera R (1982) Earthworm populations in a Venezuelan rain forest. Pedobiologia 23: 437-443

Piearce TG (1983) Functional morphology of lumbricid earthworms with special reference to locomotion. J Nat Hist 17 (1): $95-111$

Reddy MV, Pasha M (1993) Influence of rainfall, temperature and some soil physico-chemical variables on seasonal population structure and vertical distribution of earthworms in two semi-arid tropical grassland soils. Int $\mathbf{J}$ Biometeor 37: 19-26

Satchell JE (1955) Some aspects of earthworm ecology. In: Kevan D. K. Mc. E. (ed.). Soil Zoology. Butterworth, London, UK. pp. 180-201

Saussey M (1956) Un cas de commensallisme chez les lombriciens. Bull Soc Fr 81: 411-413

Senapati BK (1980) Aspects of ecophysiological studies on tropical earthworms (Distribution, population dynamics, production, energetics and their role in the decomposition process). Ph. D. Thesis, Sambalpur University, India. $154 \mathrm{p}$ 
Shannon CE, Weaner W (1949) The mathematical theory of communication. University of Illinois Press, Urbana, Il

Vegter JJ (1983) Food and habitat specialisation in coexisting springtails (Collembola, Ebntomobryidae). Pedobiologia 25: 253-262 


\section{LEGENDS}

Fig. 1 Yearly average vertical distribution of some earthworm species in savanna and pasture: a)

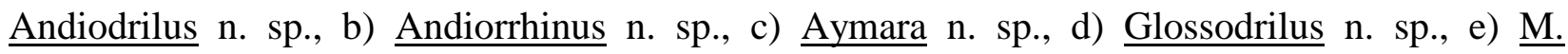
carimaguensis, f) Ocnerodrilidae n. sp. $\square$ savanna; $\square$ pasture.

Fig. 2 a) Correlation between the relative length (L/D) and the mean depth for several species (๑:Savanna, O:Pasture). And: Andiodrilus n. sp.; Anr: Andiorrhinus n. sp; Aym: Aymara n. sp.; Glo: Glossodrilus n. sp.; Mca: M. carimaguensis; Ocn: Ocnerodrilidae n. sp. Not significant (p > 0.05). b) Correlation between the relative weight (W/D) and the mean depth for several species (๑:Savanna, O:Pasture). And: Andiodrilus n. sp.; Anr: Andiorrhinus n. sp; Aym: Aymara n. sp; Glo: Glossodrilus n. sp.; Mca: M. carimaguensis; Ocn: Ocnerodrilidae n. sp. Not significant (p > $0.05)$.

Fig. 3 Vertical distribution of aestivation for $\underline{M}$. carimaguensis in pasture according to age structure.

Fig. 4 Average weight of aestivated individuals at different depths for $\underline{M}$. carimaguensis (bars indicate standard deviation).

Fig. 5 a) Yearly average vertical distribution of cocoons for Andiodrilus n. sp. in the savanna (grey) and in the pasture (black); (hand-sorting method). b) Yearly average vertical distribution for Glossodrilus n. sp. cocoons in the savanna (grey) and in the pasture (black); (washing/sieving method). c) Yearly average vertical distribution for $\underline{M}$. carimaguensis cocoons in the savanna (grey) and in the pasture (black). (Hand-sorting method).

Fig. 6 Seasonal variations of soil moisture content at $0-10 \mathrm{~cm}$ depth in the savanna and pasture systems.

Fig. 7 Soil moisture content at different depths in wet (July 1994) and dry (February 1995) 
seasons in both systems studied.

Fig. 8 Seasonal variations in vertical distribution for two species in the pasture system at four different dates: M. carimaguensis (left column) and Glossodrilus n. sp. (right column). a: April 1994; b: August 1994; c: October 1994; d: January 1995. 


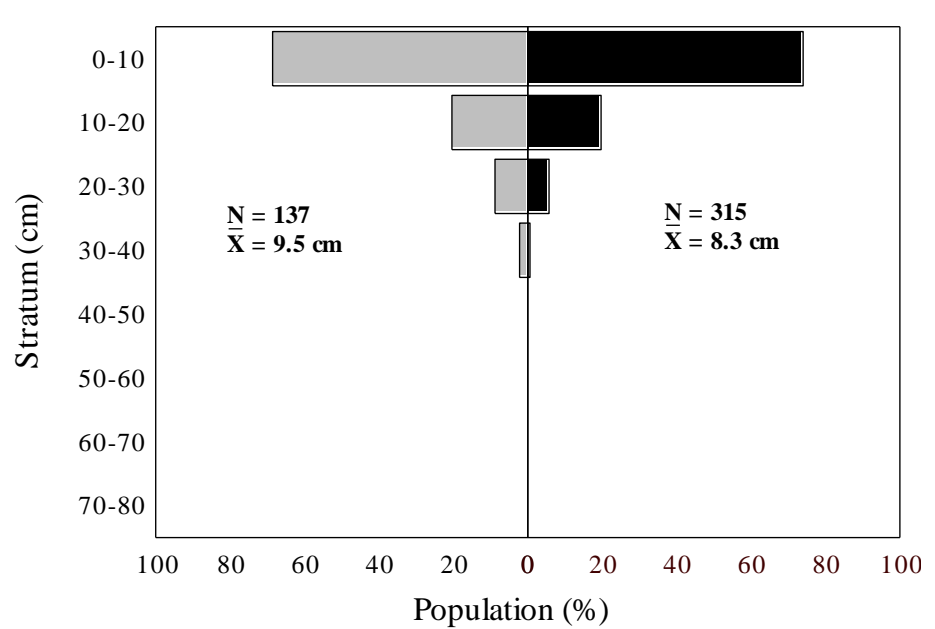

a)

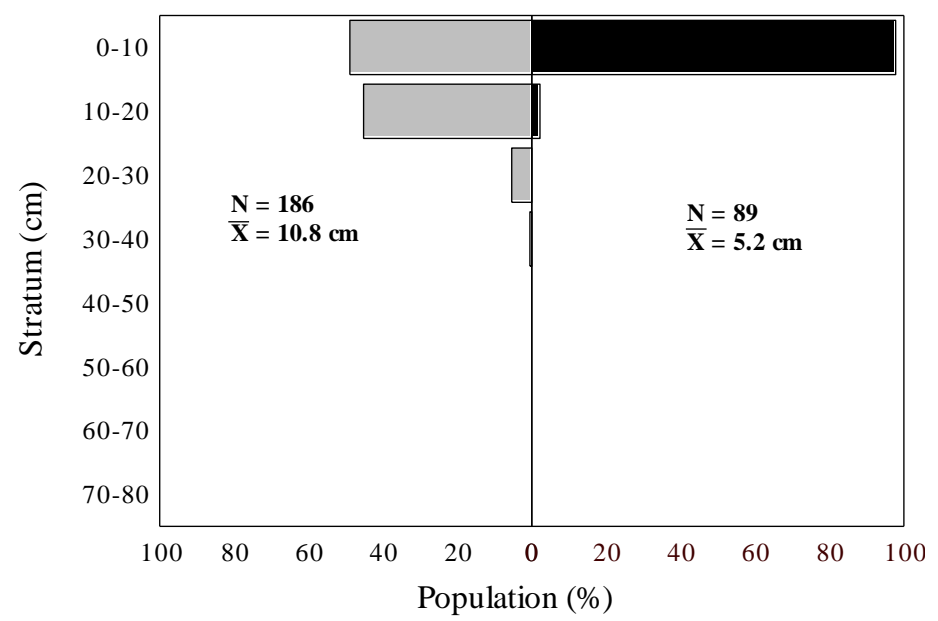

c)

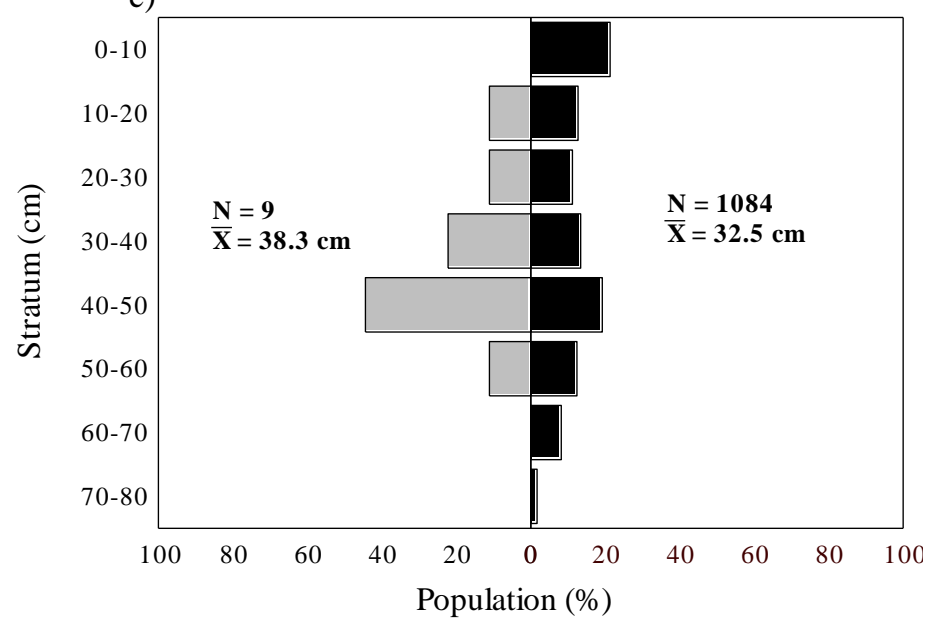

e)

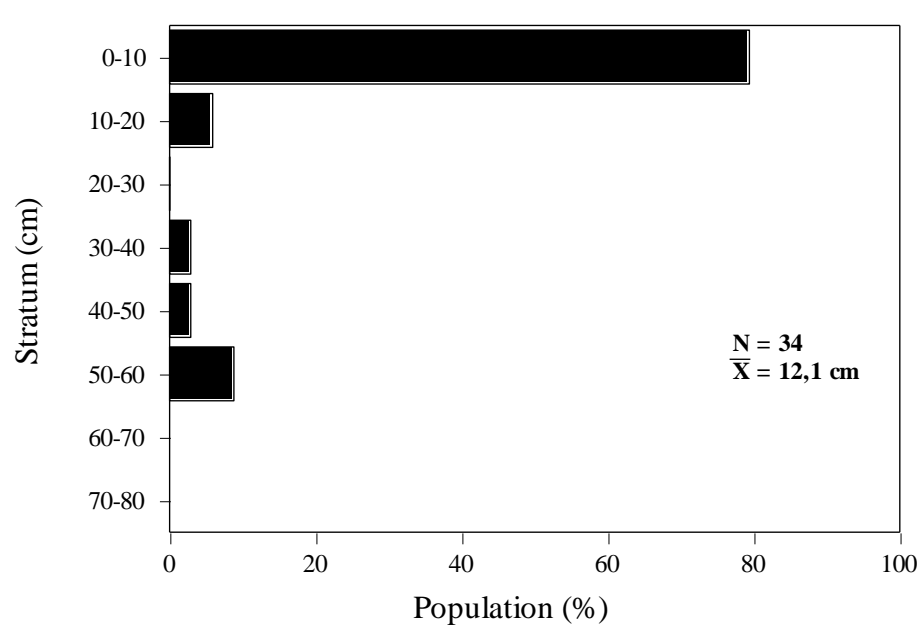

b)
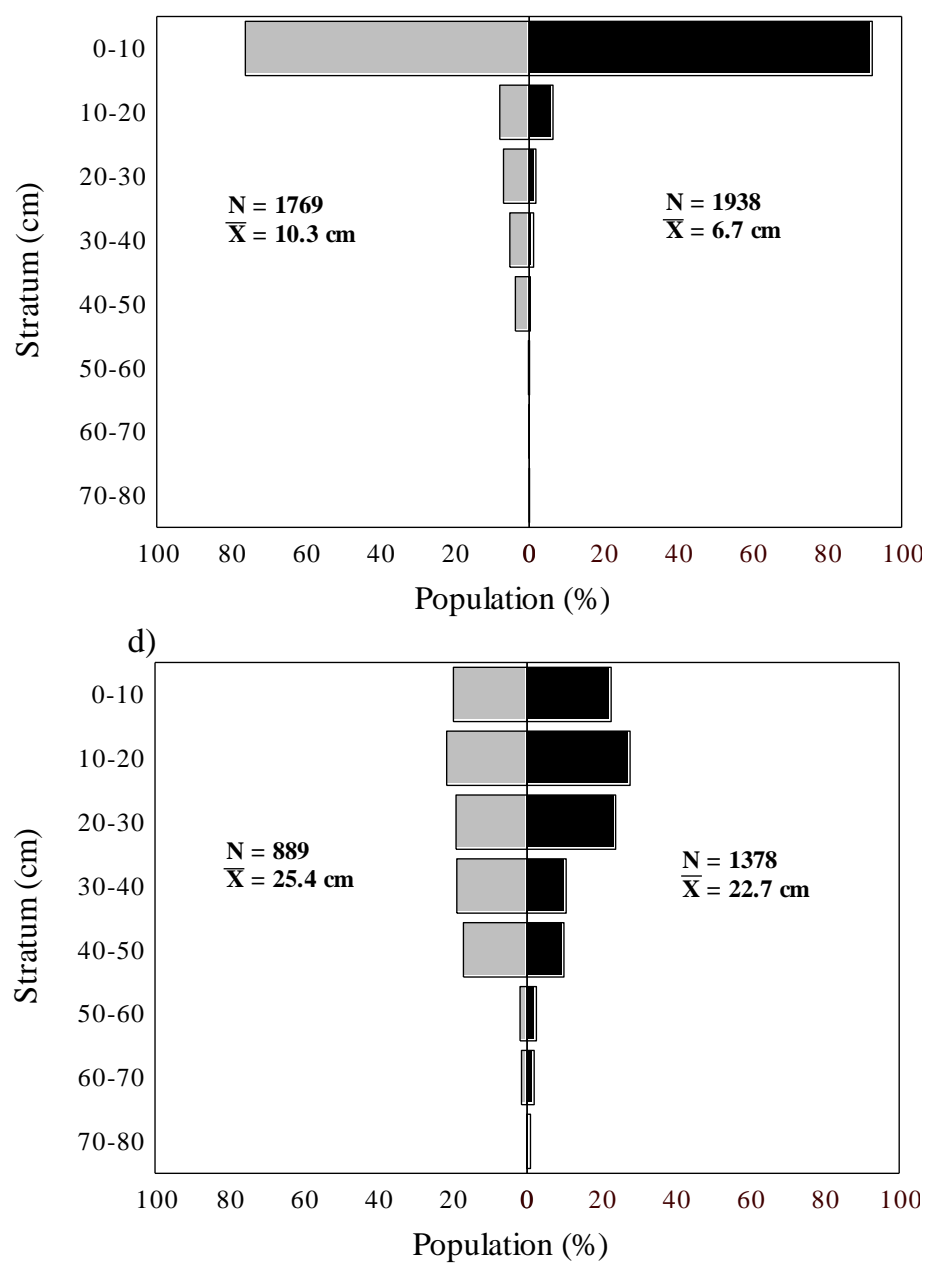

f)

Figure 1 


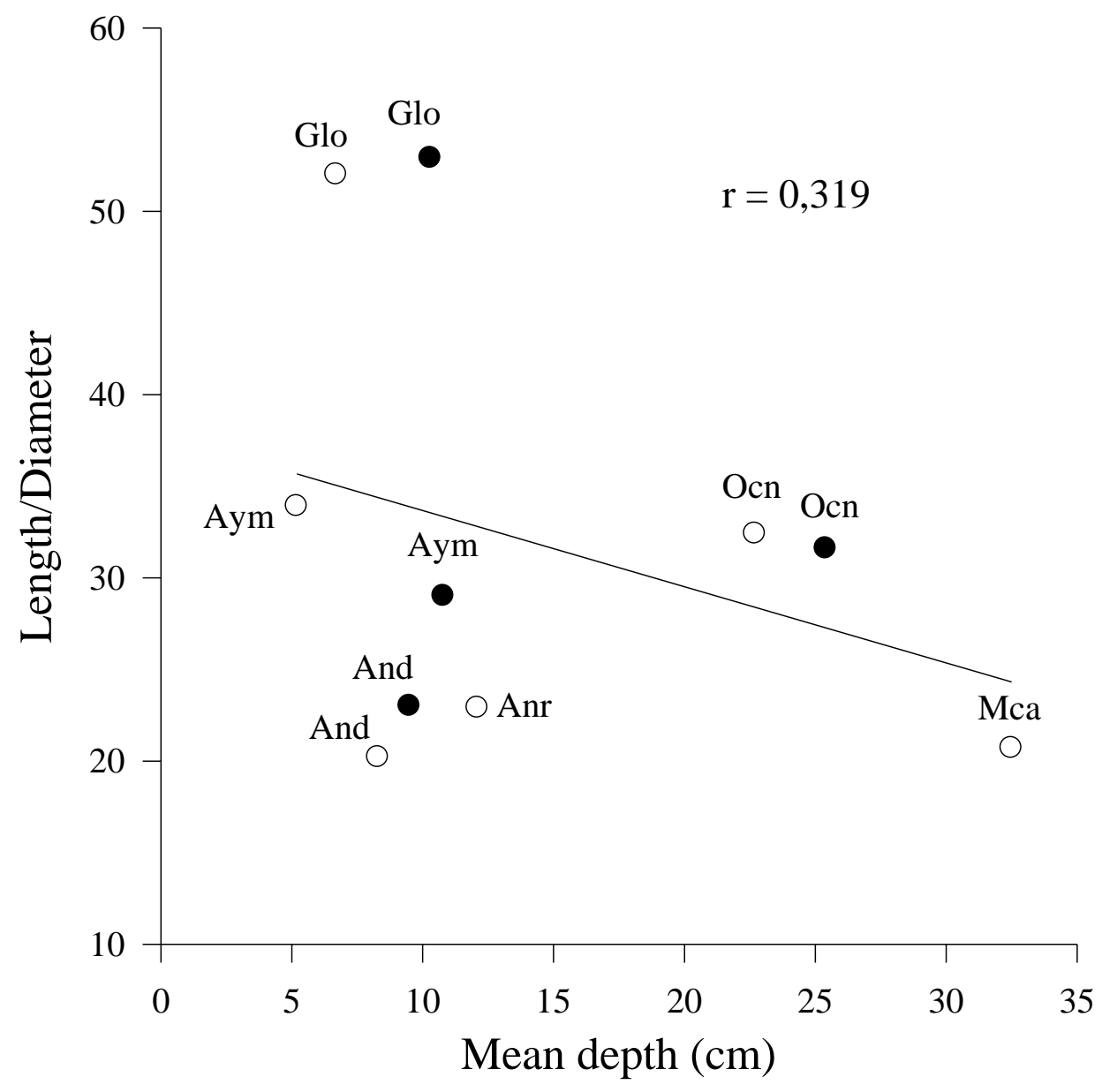

Fig. 2a 


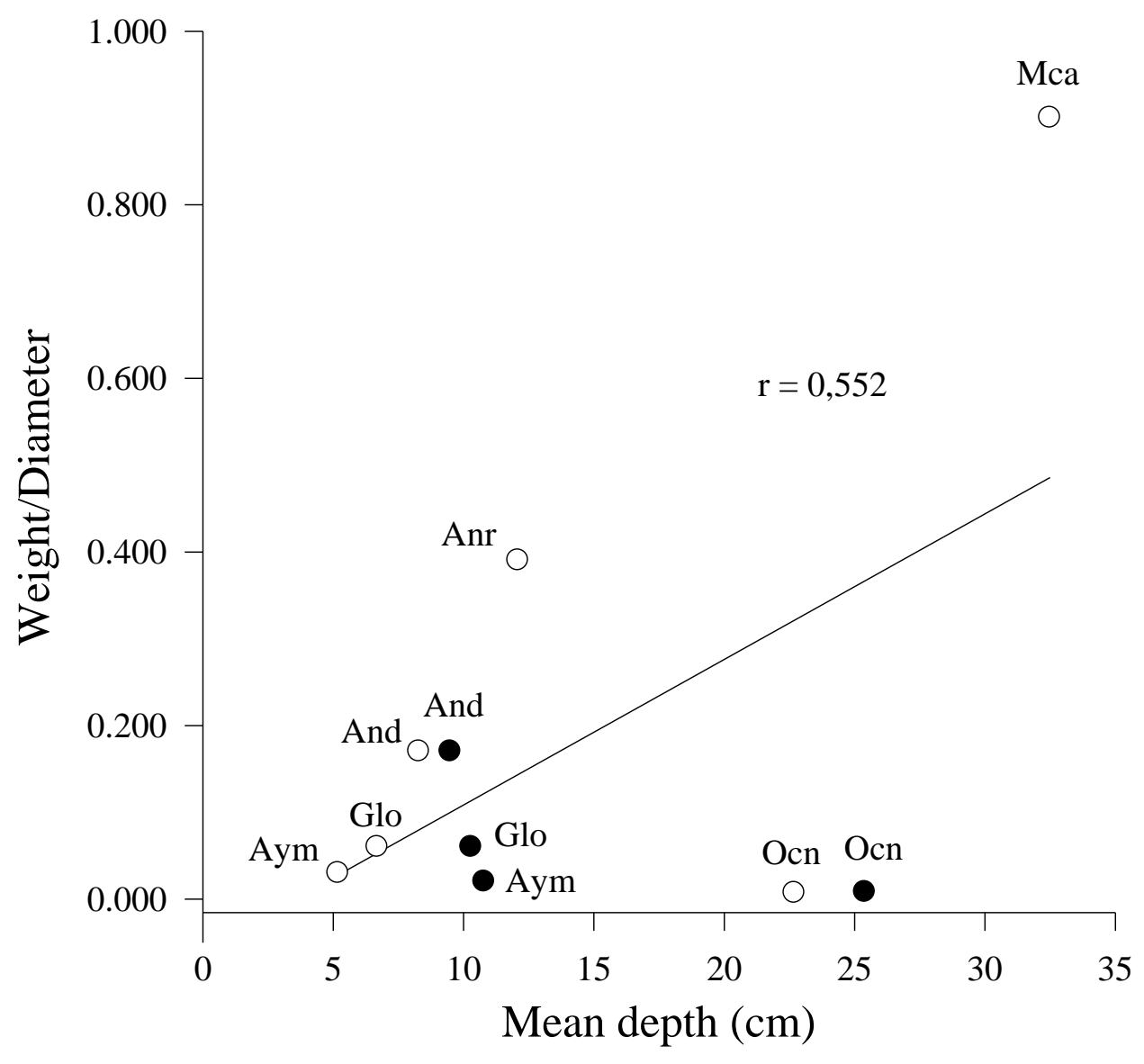

Fig. 2b 


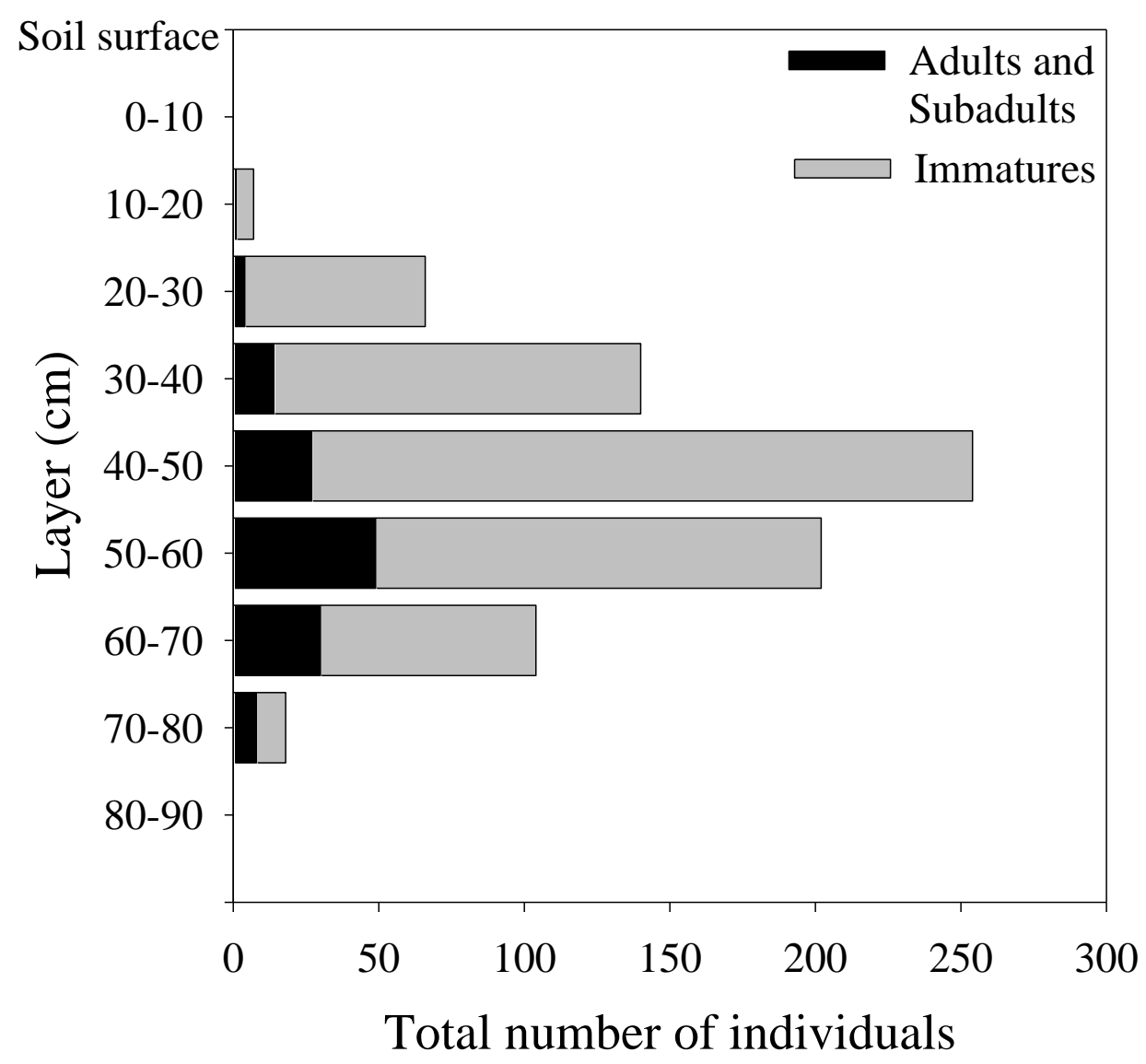

Fig. 3 


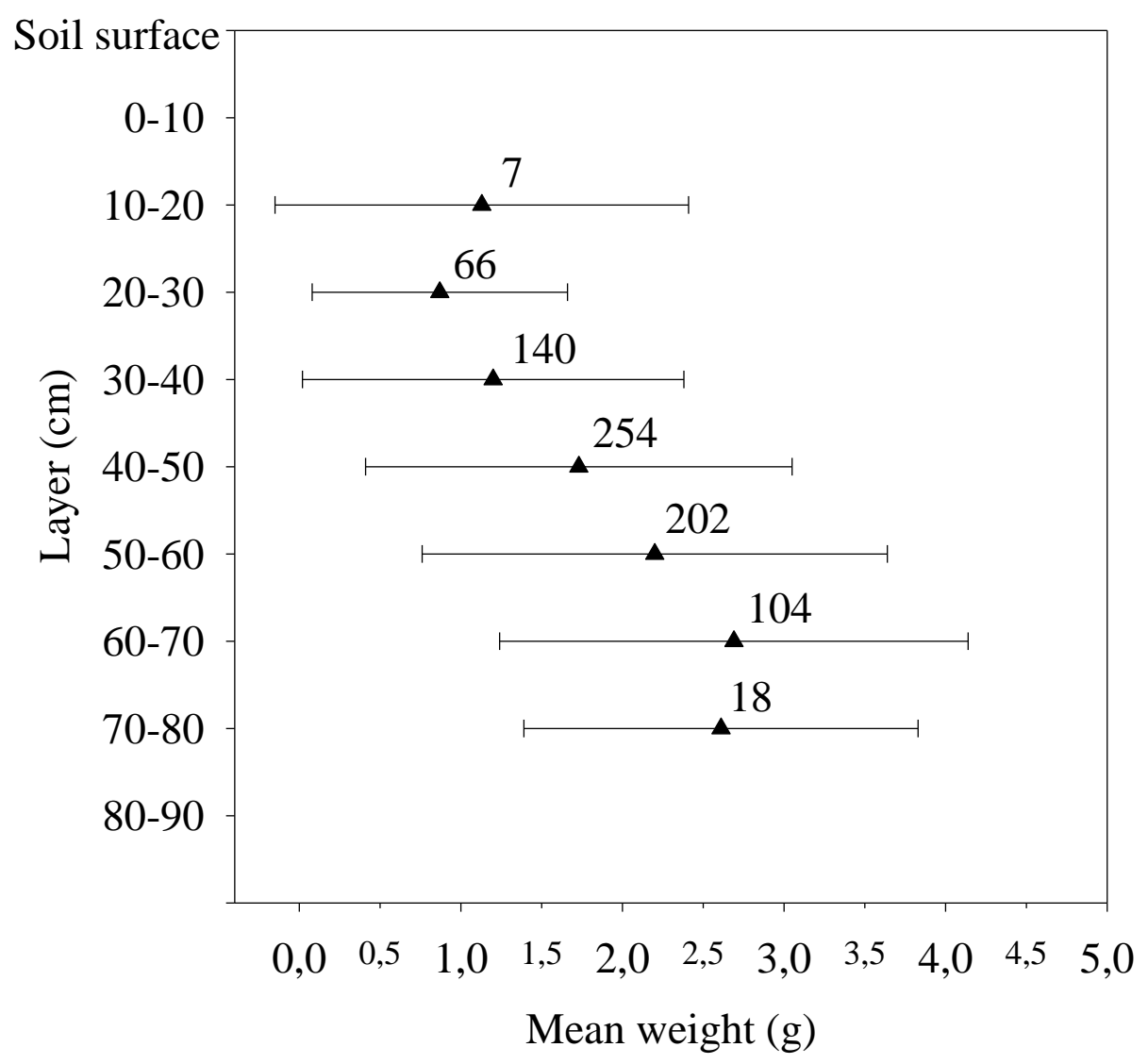

Fig. 4 


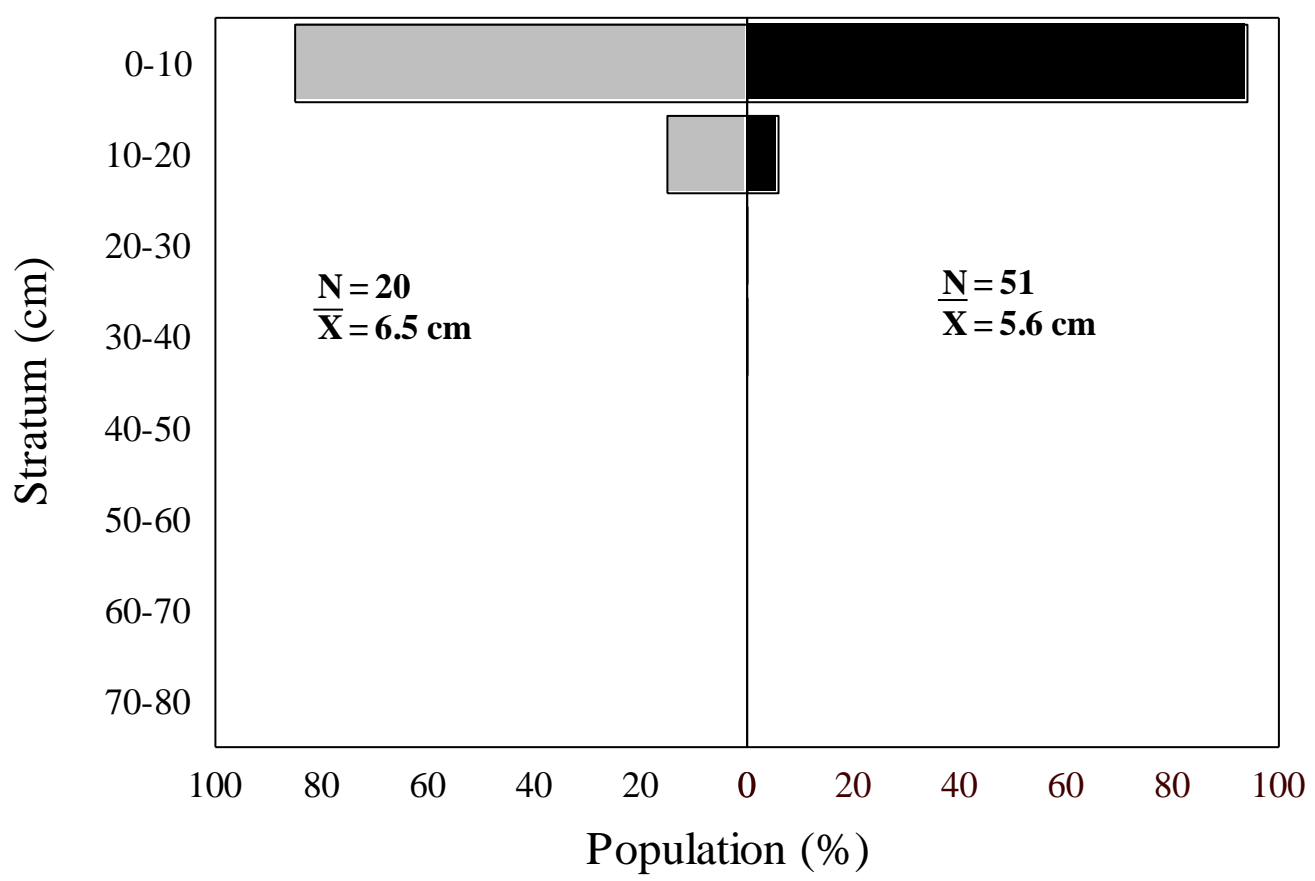

a)

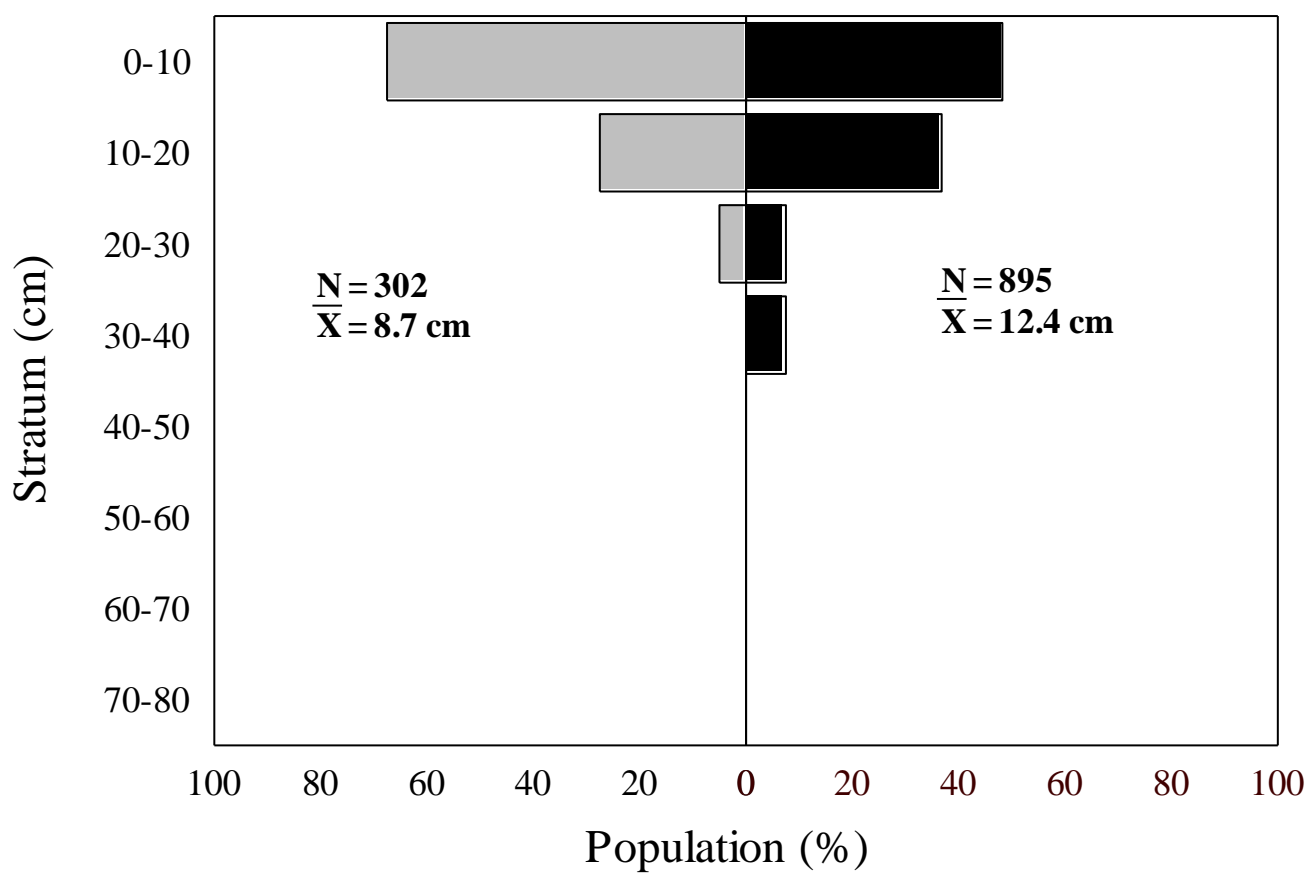

b)

Fig. 5 


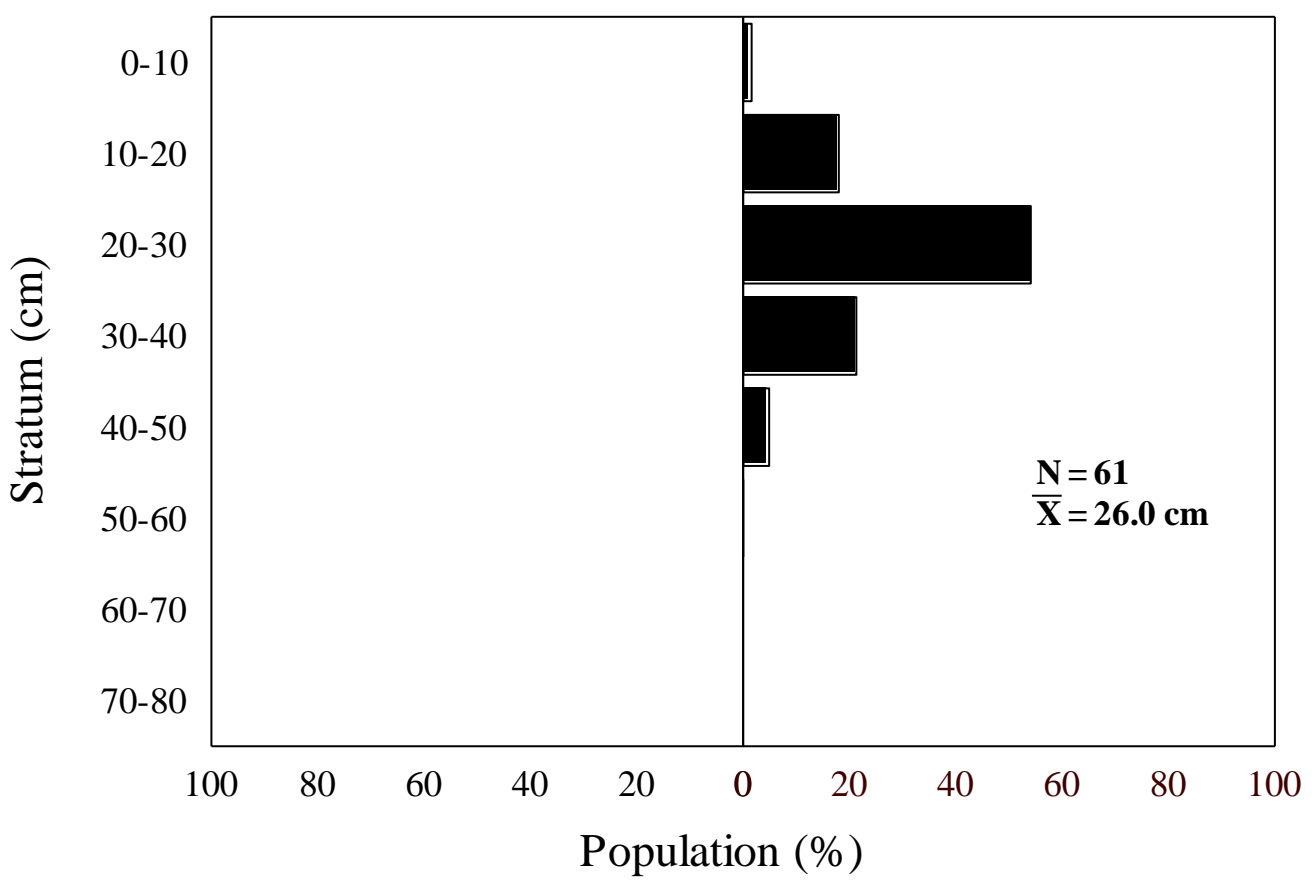

c)

Fig. 5 


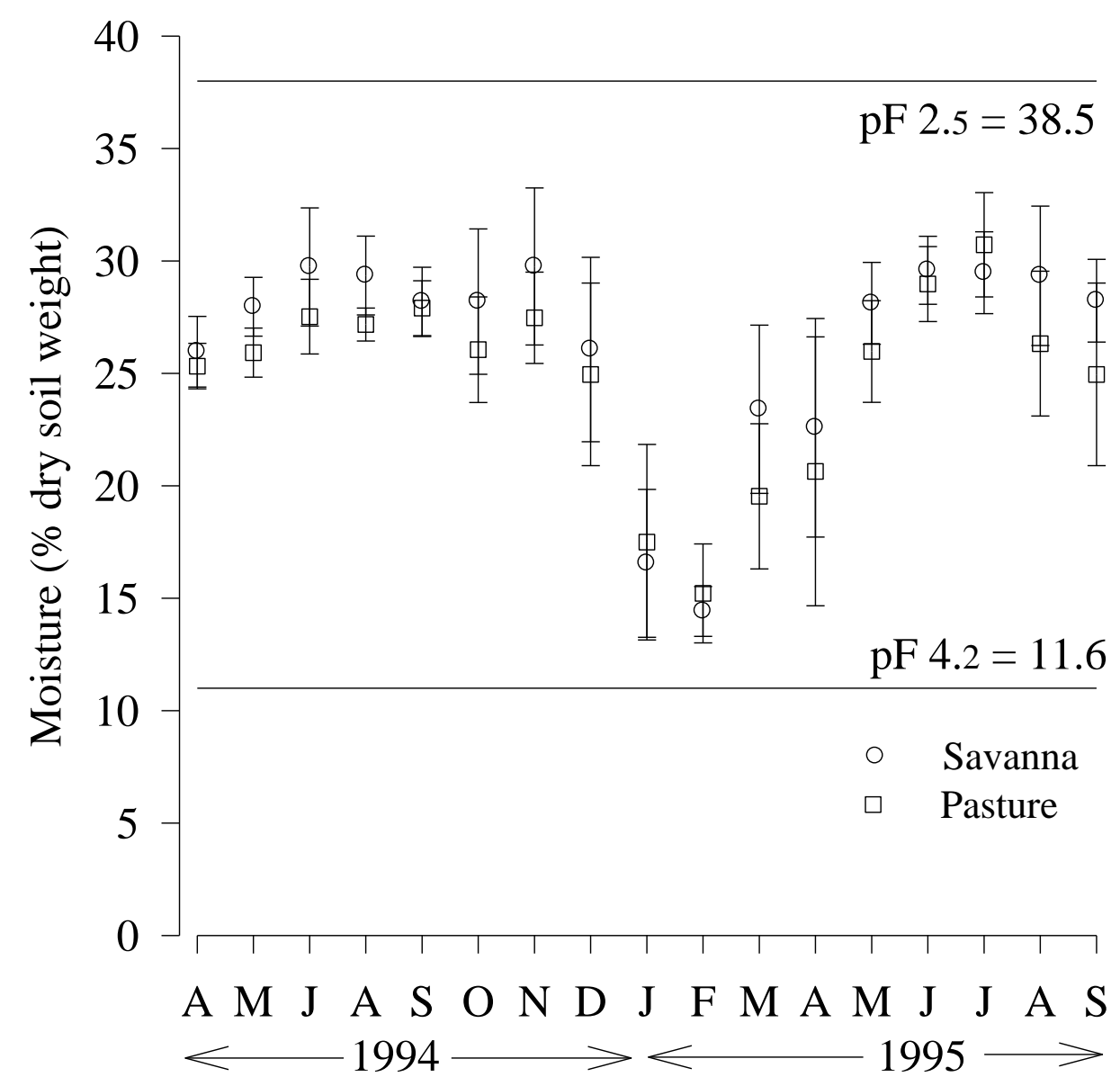

Fig. 6 


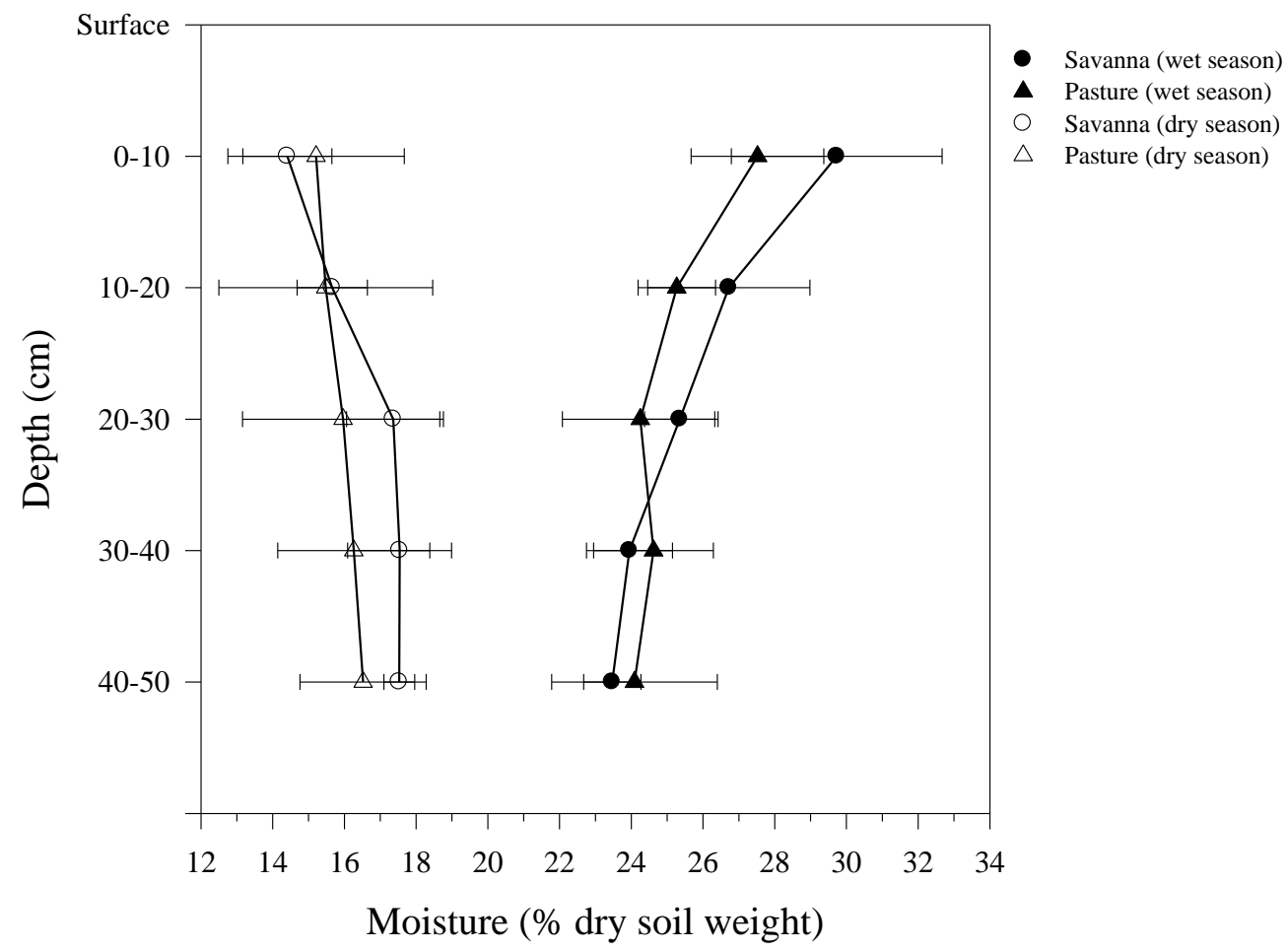

Fig. 7 

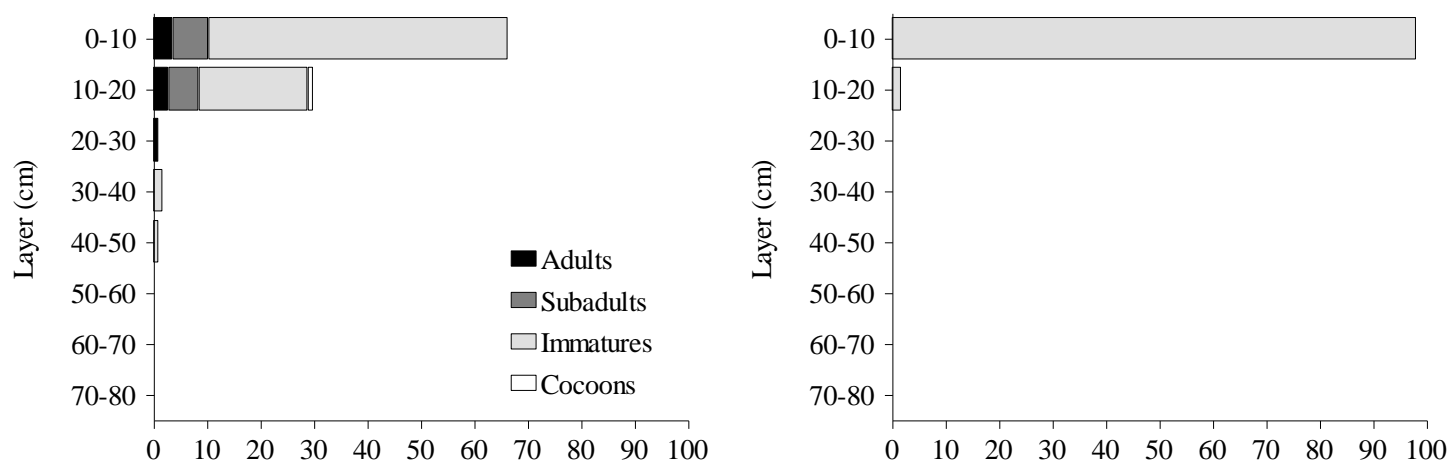

a)
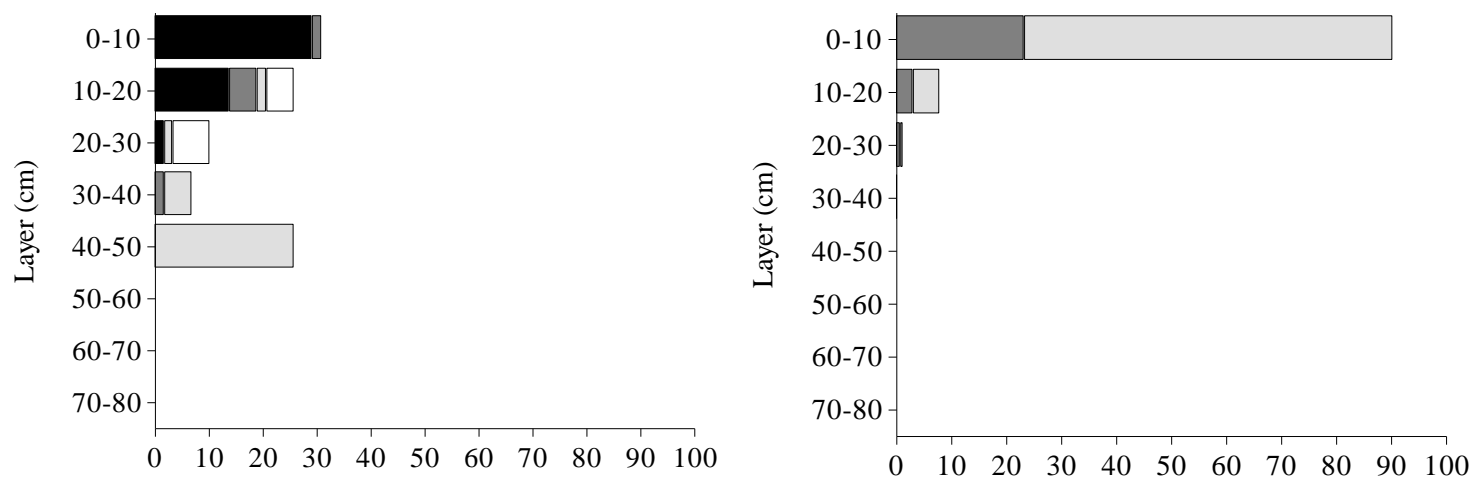

b)
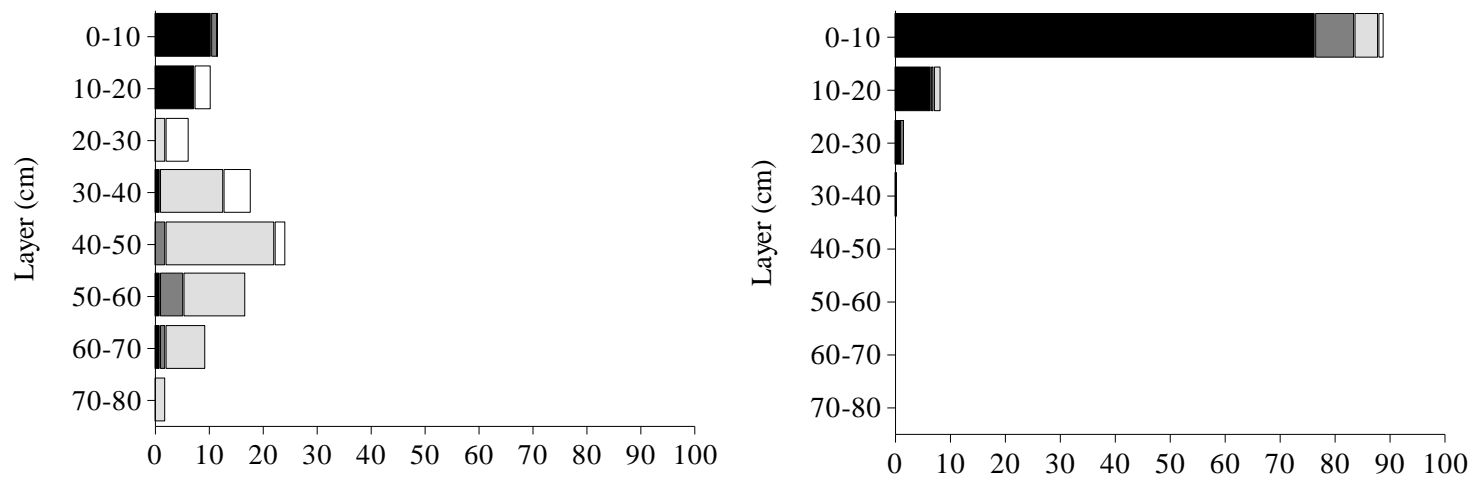

c) 

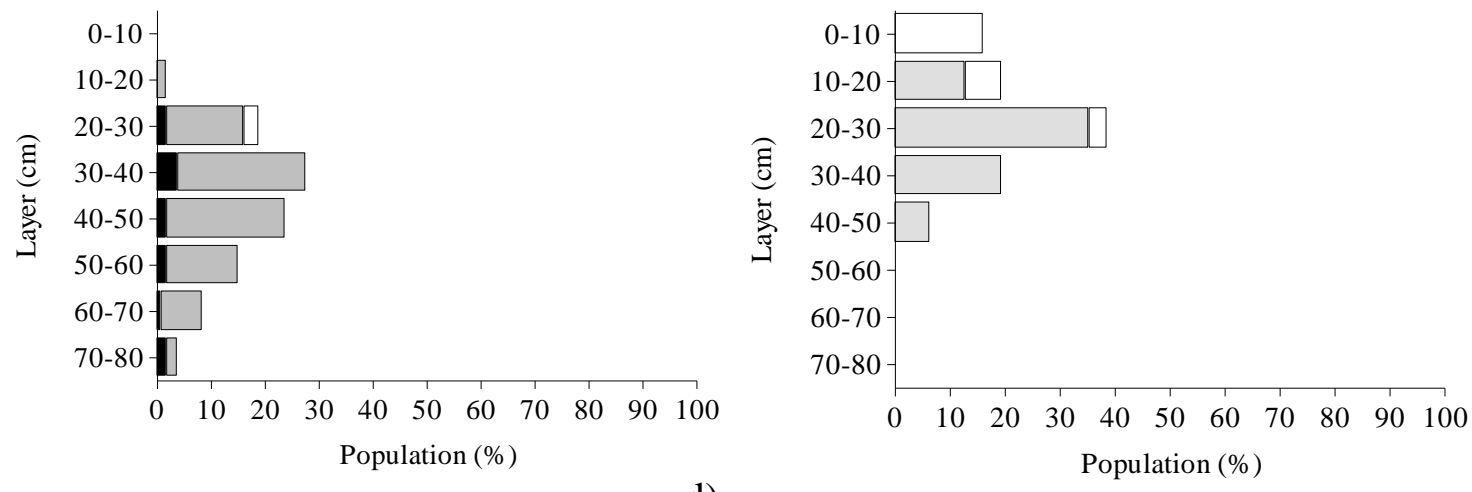

Fig. 8 


\section{TABLE CAPTION}

Table 1 Yearly average living depth $(\mathrm{cm})$ for some earthworm species from Carimagua.

\begin{tabular}{llll}
\hline Species & Ecological category & Native savanna & Introduced pasture \\
\hline Andiodrilus n. sp. & Endogeic (mesohumic) & $9.5 \mathrm{a}$ & $8.3 \mathrm{a}$ \\
Andiorrhinus n. sp. & Endo-anecic & $\mathrm{ND}^{1}$ & 12.1 \\
Aymara n. sp. & Epigeic & $10.8 \mathrm{a}$ & $5.2 \mathrm{a}$ \\
Glossodrilus n. sp. & Endogeic (polyhumic) & $10.3 \mathrm{a}$ & $6.7 \mathrm{a}$ \\
M. carimaguensis & Anecic & $39.3 \mathrm{a}$ & $32.5 \mathrm{~b}$ \\
Ocnerodrilidae n. sp. & Endogeic (polyhumic) & $25.4 \mathrm{a}$ & $22.7 \mathrm{a}$ \\
\hline
\end{tabular}

${ }^{1}(\mathrm{ND}=$ not determined $)$

Values followed by different letter indicate significant differences (ANOVA, $\mathrm{P}<0.001 * * *$ )

Table 2 Biometric characteristics of the earthworm community of the savanna and pasture plots (data are means \pm standard deviation).

\begin{tabular}{|c|c|c|c|c|c|c|}
\hline & \multicolumn{2}{|c|}{ L/D } & \multicolumn{2}{|c|}{ W/D } & \multicolumn{2}{|c|}{$\mathrm{N}$} \\
\hline & Savanna & Pasture & Savanna & Pasture & Savanna & Pasture \\
\hline Andiodrilus sp. & $23.0 \pm 3.5$ & $20.2 \pm 4.3$ & $0.17 \pm 0.1$ & $0.17 \pm 0.1$ & 31 & 52 \\
\hline Andiorrhinus sp. & ND & $22.9 \pm 0.7$ & ND & $0.39 \pm 0.2$ & ND & 24 \\
\hline Aymara sp. & $29.0 \pm 5.1$ & $33.9 \pm 5.3$ & $0.02 \pm 0.01$ & $0.03 \pm 0.01$ & 64 & 23 \\
\hline Glossodrilus sp. & $52.9 \pm 4.8$ & $52.0 \pm 6.2$ & $0.06 \pm 0.01$ & $0.06 \pm 0.01$ & 68 & 99 \\
\hline$\underline{\text { M. carimaguensis }}$ & ND & $20.7 \pm 0.6$ & ND & $0.90 \pm 0.4$ & ND & 99 \\
\hline Ocnerodrilidae n. sp. & $31.6 \pm 1.0$ & $32.4 \pm 0.9$ & $810^{-3} \pm 0.002$ & $710^{-3} \pm 0.002$ & 135 & 198 \\
\hline
\end{tabular}

$\mathrm{N}=$ number of observations 